DOI https://doi.org/10.32841/2409-1154.2020.46-1.49

\author{
Lomakina L. V., \\ Senior Lecturer at the Department of English for Technical Purposes № 1 \\ National Technical University of Ukraine "Igor Sikorsky Kyiv Polytechnic Institute"
}

\title{
FOREIGN LANGUAGE TRAINING IN SPECIAL CONDITIONS
}

Summary. The article proposes to consider the problem associated with changes in the modern information and education environment, changes of sources and content, forms and methods of providing information. The current state of implementation of distance learning in educational institutions and the existing shortcomings of the organization of this form of education during quarantine are analyzed. According to our observations, the use of a wide variety of information communication technologies for distance learning makes it difficult for students to get new knowledge and skills, overloads them and disorganizes them. The lack of a unified learning environment in such "distance learning" with a clear schedule of training sessions and an established system of interaction between training participants and students' independent educational activities, dispels students' concentration, reduces motivation for learning and increases the level of mental tension. Necessary means have been identified for the effective organization of foreign language distance learning. The components of the distance course and the obligatory content elements in its structure are highlighted. The main functions and competencies that a tutor must have to implement the conditions for successful training in a distance foreign language learning course are defined. For the effective implementation of distance foreign language learning, one of the key tasks is the pedagogically balanced selection of software, taking into account the needs and capabilities of the educational institution. On the basis of such software, distance communication between a tutor and students should be implemented, access to electronic educational resources for educational purposes should be provided and an appropriate level of education should be maintained. As an example, the use of a special distance learning platform "Sikorsky" is given. It is noted that this platform is a university open virtual learning environment, which provides administrators, teachers and students with ample opportunities for the use of modern distance learning technologies, the development of web resources for academic disciplines, the organization of interactive interaction between teachers and students, as well as management of distance learning process.

Key words: information communications, virtual learning environment, modern information technologies, distance learning systems, distance learning platform.

Problem statement. Distance education exists all over the world, occupies its socially significant place in the educational sphere. World experience convincingly shows that virtual universities are needed, they are really in demand.

It is known that in Western Europe there are such educational institutions and associations as: e-university NETTUNO, which unites 38 universities from five countries, the British Open University (Open University), the International Council for Distance Education (ICDE), the European Distance Learning network (EDEN), European Association of Distance Learning Universities (EADTU).
At the end of 1997, there were about 1,000 distance learning institutions in 107 countries. The number of those who received higher education in the distance education system in 1997 was about 50 million people, in 2000 - 90 million; according to forecasts in 2023 will be 120 million people [1]. Distance learning of a foreign language is developing in the general system of distance education. The gradual development of the system of foreign language teaching is given on the example of The National Technical University of Ukraine "Igor Sikorsky Kyiv Polytechnic Institute" (NTUU KPI): 1) 1998 - Multimedia and Internet-based teaching of foreign languages at the Faculty of Linguistics; teaching disciplines: "Engineering and Applied Linguistics" and "Intelligent Information Technologies"; 2) 2000 - introduction of the distance course "Business English" at the International University of Finance (structure of NTUU KPI); 3) 2001 - the opening of the Ukrainian Center for Distance Education and the implementation of a business English course based on the Lotus Learning Space; 4) 2003 - creation of a library of electronic teaching materials in English; 5) 2004 creation of a website for the Department of English, containing a set of educational and methodological materials of English language for professional purposes (specialties NTUU KPI); 6) 2005 - creation of multimedia laboratories for studying of foreign languages at the faculties of NTUU KPI and the beginning of the mass application of information technologies in foreign language teaching; the creation of the Ukrainian Center for Information Technologies in Education and the opening of the Central-Eastern European Virtual University (CEEVU) and the development of distance English-language courses for professional communication.

The issues of education informatization, in one or another aspect of the manifestation of its complex and multifaceted content, were identified by the National Academy of Pedagogical Sciences of Ukraine (APN of Ukraine) at the level of priority directions of scientific research in 2018-2022. Among such directions, the general meeting of the NAPS of Ukraine, by its decision of 17.11.2017, resolved: theoretical and methodological, methodical and technological principles of informatization of education; information and analytical support of educational activities, design of information and educational environment and electronic resources; formation of a networked educational environment and its integration with traditional learning systems; formation of information culture of subjects of the educational process and ensuring information security of educational activities in networks; development and implementation of computer-oriented training systems, multimedia technologies, electronic resources and teaching aids based on information and communication technologies (ICT) [2].

In 2013, the Order of the Ministry of Education and Science of Ukraine approved the "Regulations on Distance Learning" [3], which defines the basic principles of organizing and implementing distance learning in Ukraine. 
Due to the threat of the coronavirus COVID-19 spread in Ukraine, by the decision of the Cabinet of Ministers [4], [5] from March 12, 2020, quarantine measures have been introduced for a long time, which prohibit applicants from visiting educational institutions throughout the country.

In such circumstances, the heads of educational institutions and institutions of preschool, general secondary, vocational, professional, higher and postgraduate education for the period of quarantine are obliged to provide the organization of the educational process on the basis of distance learning technologies [6].

Most of the teachers are aware of this form of organization of the educational process, but only a few have used its elements in their professional activities or for self-education. However, teachers today must quickly and effectively apply the latest technologies, methods and forms of education. As part of the reform of education and science, for this purpose, it is envisaged to create an educational portal with methodological and didactic materials, Ukrainian e-encyclopedias, multimedia textbooks and interactive online resources [7].

The primary task defined in the Concept for the Development of the Digital Economy and Society of Ukraine for 2018-2020 is the formation of a thorough national policy of digitalization of education as a priority component of the education reform, one of the main directions of which is the development of distance education using cognitive and multimedia technologies [8].

Analysis of recent research and publication. A great contribution to solving the scientific and applied problem of digitalization of education has been made by domestic and foreign scientists. V. Yu. Bykov notes that "among modern educational technologies that appeared at the end of the twentieth century and are now noticeably widespread in developed countries, are distance learning technologies that support and provide distance education (DL) [9]. To the main advantages of distance learning O.P. Mukoviz, K.R. Kolos and N.A. Kolomiiets include: automatic and timely updating of versions of the required software and electronic educational resources (EER), secure protection against unauthorized access, the possibility of simultaneous access of several users to educational resources and the ability to use resources anywhere or anytime [10]. M.I. Zhaldak, T.I. Koval, Yu.V. Trius, N.G. Syrotynko, A.V. Rybalko, N.E. Tverdokhliebov and others highlighted the basics of using distance learning technologies in the training of future specialists, including teachers.

Among the latest scientific works of foreign scientists, attention should be paid to how N. Levinsky, J. Muller, J. O'Rourke, D. Parrish; R. Phillips characterized the pedagogical and informational support of distance learning. Rebecca B. Reynolds notes that during the quarantine period, the so-called "emergency distance learning" is introduced, which is not identical to distance learning. The scientist notes that "the main goal of such training during a crisis is to quickly provide temporary reliable access to training and pedagogical support, but not the creation of a reliable educational ecosystem" [11].

At the same time, the problem of foreign language distance learning remains unresolved. Available research on the technology of organizing foreign language distance learning mostly carried out under normal conditions, without taking into account modern challenges caused by quarantine. Now, in conditions of isolation due to quarantine restrictions, for education organizers, teachers and students, problems of the institutional level have arisen the lack of the possibility of using other forms of education, the lack of access to the premises of the educational establishment.
At the level of the educational institution, there is a need for a more coordinated organization of the educational process, in particular, the teachers' selection and use of not only one or a limited number of platforms within the educational institution with the required level of information security and health preservation, but also the selection of recommended software tools that should be installed outside the educational institution on the students' personal devices for their work with files of certain types and formats.

This largely applies to foreign language teachers, who have to provide appropriate Internet access, use their own software-hardware and technical means of information and communication technologies, handle and maintain them in working order at their own expense.

At the same time, problems and challenges at the institutional level may be exacerbated by regional challenges associated with the different levels of infrastructure development of different territories, communities, settlements and their individual areas, in particular, the low speed and quality of data transmission in the relevant Internet segments, and sometimes the lack of access to the network.

This necessitates the organization of an effective system of foreign language distance learning under quarantine conditions, the elements of which can be successfully used in traditional and inclusive education.

The purpose of the article. The purpose of the study is to analyze the structure of technologies for distance learning of a foreign language in quarantine conditions.

Research. Based on the concept of creating and developing a unified system of distance education in Ukraine and the methodological prerequisites for learning a foreign language as a means of foreign language communication, it can be concluded that improving of foreign language teaching at a university depends on the implementation of such fundamental issues of organizing the educational process as: rejection of the authoritarian style of teaching; orientation to the personal qualities of the subject of training; improvement of training technologies for academic disciplines, namely: avoiding the monologue as a traditionally predominant form of educational activity, and the development of such a form of teaching as polylogue (communication, conversation, discussion); understanding of foreign language communication not only as a ability to transform information into a structure and forms of a foreign language, but also as an inducement of a partner to some action of linguistic and non-linguistic order, as well as the realization of the self-expression of the interlocutor; understanding of knowledge not as impersonal information, but a set of skills that are actualized in the system of the subject's activity.

Therefore, one of the most important directions of distance learning at the Faculty of Linguistics of NTUU KPI is the creation and use of a single educational environment and the creation of own curricula. At the same time, programs should include both the basic level of grammar, phonetics, vocabulary, listening for those who begin to study a foreign language at the university, and the level for undergraduate students, including journalistic articles; unadapt texts, native speakers' audio recordings and simultaneous translation functions.

Distance education is an individualized process of education, which occurs mainly through the indirect interaction of distant participants of the educational process in a specialized environment functioning on the basis of modern psychological, pedagogical, information and communication technologies [12]. V.Yu. Bykov 
determines that distance education is a form of organization and implementation of the educational process, in which its participants carry out educational interaction (both synchronously and asynchronously in time) fundamentally and predominantly extraterritorially based on digital technologies [9, p. 191].

A distance course is a set of teaching materials and educational services created in a virtual educational environment for the organization of distance learning based on information and communication technologies [9, p. 115].

Distance learning is an interactive process based primarily on the paradigm of modern education, which is aimed at creating an interactive communication network space, identifying the individual characteristics of each participant, encouraging him for finding an independent problems' solution, to self-education [13].

The main components of the distance course are the systems of learning materials and training services. The system of educational materials includes: structured electronic interactive educational materials placed in a computer-oriented learning environment; printed materials (textbook, reference notes, workbook, guidelines for teachers) are developed in accordance with the specifics of the course; additional educational tools and educational information carriers of reference and encyclopedic nature (links to external resources: videos, documents, tests, etc.).

The system of training services (educational services) implements the functions of cooperation (delivery of learning materials to the student, creation of conditions for adaptation at the beginning of training, motivation throughout all educational process, ensuring interactive interaction of training participants) and the organization of students' independent study with self-assessment and control of knowledge and skills before training, during training, at the end of training.

When developing a distance learning course in a foreign language, it is advisable to use a weekly course format, which provides time for students to process learning materials independently or with the tutor's support in accordance with the curriculum, for doing homework or for recreation, hobbies and self-improvement.

Consider an example of the structure of a distance foreign language learning course for a separate group. In such a structure, it is necessary to provide: 1) the entire period of distance learning is divided into weeks: the dates of each of the academic weeks are indicated; 2) according to the schedule, the date of training and its duration are indicated for each week; 3 ) teachers fill each of these lessons with content, choosing the necessary activities (tasks, test, choice, seminar, etc.) and resources (page, file, URL links, etc.).

Mandatory content elements in the structure of the distance course: 1) introduction and course news (foreword; name, purpose, general information, scope, training duration, learning outcomes, requirements for students; a short description of training organization); 2) course program (a list of weekly classes with the topic title, the purpose of learning topic, week work plan, theoretical material, practical tasks, testing, glossary and library (recommended sources, resources, sites, etc.); abstract of theoretical and practical material; methodological guidelines for practical tasks; a list of the main elements of the distance course (textbook, background notes, etc.).

Distance foreign language learning course, located in a virtual learning environment, provides: management and administration of the educational process; providing knowledge by studying theoretical material; self-control; knowledge-based skills and habits; joint activities of students in small groups; synchro- nous and asynchronous communication; control over the assimilation of theoretical material; implementation of practical tasks and their monitoring [13, p. 109].

In distance learning of a foreign language, it is the tutor who is the key figure responsible for conducting classes with students, who creates an appropriate educational environment. He guides the learning process as an activity and tries to provide the planned results in terms of acquired knowledge and skills, as well as acquired students' personal abilities [13, p. 13].

Learning materials can rarely be adapted to the students' requirements, since these requirements often become known precisely during the process of training. Therefore, the tutor usually performs the adaptive role. He can help students become sufficiently autonomous and independent.

A foreign language distance course tutor does a lot of what a teacher does in traditional learning, for example, leading a group in a discussion with effective methods. However, he works in an electronic environment where participants are not accommodated in one real room at a specific time. A tutor teaches communication using different styles, approaches, language means, for example, questions, for improving the learning process in a group [13, p. 16].

For the organization of distance learning of a foreign language in an educational institution, it is important that the tutor has the following basic competencies: know the basics of telecommunication etiquette; possess information navigation skills; be able to create web pages; be proficient in a specific computer-oriented learning environment; be able to use the range of services provided by this environment; know the methods of activating students' activity in the network and be able to use them in distance learning; know active training methods (collaborative training, project method, multilevel training, research and search methods, etc.); be able to conduct role-playing network games; determine, through feedback, the effectiveness of students' learning activities; carry out high-quality semantic content of the distance learning course; identify problems with students' registration, record keeping, etc.; actively use the communicative capabilities of computer networks to organize communication between participants in the educational process.

A competent tutor is able to create a learning environment in which participants learn the essence, together generate ideas and thoughts. But the main person of distance foreign language learning is a student, so the following indicators should assess the effectiveness of learning: students' attitude to distance learning course; students' satisfaction with the learning process; students' achievements.

As a rule, a student feels comfortable in the learning environment if he is responsible for his studies: sets realistic goals; monitors his progress; reflects understanding; finds support both among tutors and among classmates [13, p. 42].

The main condition for the success of students' distance learning is a high level of motivation and self-discipline. Students evaluate the quality and positive features of the tutor interaction through reliable and timely feedback. During their training, students need advice on: planning the day's schedule; self-organization; improving learning skills; solving technical problems; completing educational tasks; informal learning with other students; self-assessment of knowledge quality; fulfillment of the tutor's requirements; execution of tests and control tasks [13, p. 50].

For the effective implementation of distance foreign language learning, one of the key tasks is the pedagogically balanced selec- 
tion of software, taking into account the needs and capabilities of the educational institution. On the basis of such software, distance communication between a tutor and students should be implemented, access to electronic educational resources for educational purposes should be provided and an appropriate level of education should be maintained.

However, according to our observations, the use of a wide variety of information communication technologies for distance learning makes it difficult for students to get new knowledge and skills, overloads them and disorganizes them. The lack of a unified learning environment in such "distance learning" with a clear schedule of training sessions and an established system of interaction between training participants and students' independent educational activities, dispels students' concentration, reduces motivation for learning and increases the level of mental tension.

It should be stressed, that in order to solve this problem, under quarantine conditions, for the implementation of distance learning in Igor Sikorsky Kyiv Polytechnic Institute almost 100\% of respondents use a separate distance-learning platform "Sikorsky Distance Learning Platform". This platform is a university open virtual learning environment, which provides administrators, teachers and students with ample opportunities for the use of modern distance learning technologies, the development of web resources for academic disciplines, the organization of interactive interaction between teachers and students, as well as management of distance learning process. The basic web environment on the platform is Moodle, G Suite for Education and other software products designed to implement distance learning. Currently, 175 distance foreign language-learning courses have already been registered.

At the same time, for the implementation of distance learning, teachers and students use only those ICTs with which they are familiar and have the opportunity to use them in the realization of the planned activities, in particular: for message distribution and file exchange - Viber, Telegram, Google ClassRoom, e-mail, social networks; for the presentation of educational material - Google cloud services (YouTube, Disk, Presentations, Documents, Sites, ClassRoom), Zoom, educational platforms; to monitor students' learning activities - Viber, email, Google ClassRoom, Google Forms and others.

Conclusions. During the review and analysis of the creation of a distance education system under quarantine conditions, it was found that the arsenal of information and technological means used by universities is quite diverse, and in addition, it is rapidly expanding. An analysis of the possibilities of accessing the Internet shows that in almost all regions of Ukraine, it is possible to get DL services. Teaching staff has the necessary technical support, but the biggest problem for distance learning participants is the lack of high-speed Internet access.

To implement distance learning in educational institutions, teachers use special distance learning platforms, in particular Google ClassRoom, Moodle, "Sikorsky", etc. At the same time, for the implementation of distance learning, teachers use only those software tools with which they are familiar and which they can use to implement the planned activities in distance learning.

The developed technology of organizing distance learning for students of educational institutions provides a clear, logical and systemic combination of: the necessary means for organizing distance learning; the prerequisites for using the specified electronic educational resource; the main components and structure of the distance course, contributes to the creation of conditions for learning in activities and cooperation; functions and competence of a tutor, which are necessary for the effective distance learning implementation.

The main characteristics of the DL system, which declare openness, the possibility of combining work with training, flexibility have not yet been fully realized due to insufficient development of a high-quality information and educational environment.

Further research requires identifying the methodological features of the implementation of mass distance learning for students of education institutions under quarantine conditions.

\section{References:}

1. Tatarchuk H. (2000). Institutionalization of distance learning: the sociological aspect. Obrazovanye. № 1. P. 63-72.

2. National Academy of Pedagogical Sciences of Ukraine, (2016). National report on the state and prospects of education in Ukraine. Ukraine, Kyiv: Pedagogical Thought. P. 448. October 25, 2020. URL: http://ib.iitta.gov.ua/166230/1/nac\%20dopovid\%202016.indd\%20 smal.pdf

3. Ministry of Education and Science of Ukraine. (2013). Order № 466 «On approval of the Regulations on Distance Learning». November 10, 2020. URL: https://zakon.rada.gov.ua/laws/show/z0703-13\#

4. Cabinet of Ministers of Ukraine. (2020). Decree \# $262 « \mathrm{On}$ Amendments to the Resolution of the Cabinet of Ministers of Ukraine of March 11, 2020 \# 211». November 17, 2020. URL: https://www. kmu.gov.ua/npas/pro-vnesennya-zmin-do-postanovi-ka-a262

5. Cabinet of Ministers of Ukraine. (2020). Decree \# 211 «On Prevention of Spread of COVID-19 Coronavirus on the Territory of Ukraine». December 11, 2020. URL: https://www.kmu.gov.ua/ npas/prozapobigannya- poshim110320rennyu-na-teritoriyi-ukrayinikoronavirusu-covid-19

6. Ministry of Education and Science of Ukraine. (2020). Order \# 406 «On Organizational Measures to Prevent the Spread of Coronavirus COVID-19». December 11,2020.URL: https://mon.gov.ua/ua/npa/proorganizacijni-zahodi-dlya-zapobigannya-poshirennyukoronavirusu-sovid-19

7. Government Portal: The only web portal of the executive authorities of Ukraine. (2018). Education and Science Reform. December 15, 2020. https://www.kmu.gov.ua/diyalnist/reformi/rozvitok-lyudskogokapitalu/ reforma-osviti

8. Cabinet of Ministers of Ukraine. (2018). Ordinance \# 67-r «On approval of the Concept of development of the digital economy and society of Ukraine for 2018-2020 and approval of the action plan for its implementation». December 11, 2020. URL: https://zakon.rada. gov.ua/laws/show/67-2018-\%D1\%80

9. (2008). Remote Course Development Technology / V. Bykov et al. Kyiv, Ukraine : Milenium.

10. Mukoviz O., Kolos K., Kolomiiets N. (2018) "Distance Learning of Future Primary School Teachers as a Prerequisite of Their Professional Development Throughout Life." Information Technologies and Learning Tools. V. 66. № 4. January 11, 2021. URL: https://journal. iitta.gov.ua/index.php/itlt/article/view/2265

11. Christine Greenhow, Rebecca B. Reynolds. (2020). "What are the pedagogical advantages of online learning, compared to in-person classroom learning?" Quotes from Experts: COVID-19 and Extended Online Learning. January 15, 2021. URL: https://www.sciline.org/ covid-expert-quotes/online-learning\#toc

12. Verkhovna Rada of Ukraine. (2020). Law of Ukraine «On Education». January 18, 2021. URL: https://zakon.rada.gov.ua/laws/ show/2145-19/page.

13. (2005) Distance learning process / V. Kukharenko et al. Kyiv, Ukraine : Milenium. 


\section{Ломакіна Л. В. Навчання іноземної мови в особливих} умовах

Анотація. У статті пропонується до розгляду проблема, пов'язана зі змінами в сучасному інформаційно-освітньому середовищі, зміною джерел та змісту, форм і способів надання інформації. Проаналізовано сучасний стан упровадження дистанційного навчання в закладах освіти та наявні недоліки організації цієї форми навчання під час карантину. За нашими спостереженнями, використання великого розмаїття інформаційно- комунікаційних технологій для дистанційного навчання іноземної мови певною мірою ускладнює засвоєння нових знань і вмінь студентами, перевантажує їх, дезорганізовує. Відсутність у такому «дистанційному навчанні» єдиного навчального середовища, в межах якого наявний чіткий розклад навчальних занять і налагоджено систему взаємодії учасників навчання та самостійну освітню діяльність студентів, розсіює сконцентрованість студентів, знижує мотивацію до навчання, підвищує рівень психічної напруженості. Для ефективної організації дистанційного навчання іноземної мови виокремлено необхідні засоби. Представлені компоненти дистанційного курсу та обов'язкові змістові елементи в його структурі. Визначені основні функції та компетент- ності, якими повинен володіти тьютор для реалізації умов успішного навчання в дистанційному курсі навчання іноземної мови. Для ефективного впровадження дистанційного навчання іноземної мови в закладах освіти одним із ключових завдань $€$ педагогічно виважений добір програмного забезпечення 3 урахуванням потреб і можливостей освітнього закладу. На основі такого програмного забезпечення повинне реалізовуватися не лише дистанційне спілкування тьютора й студентів, надаватися доступ до електронних освітніх ресурсів навчального призначення, а й підтримуватись належний рівень освіти. Прикладом наведено використання спеціальної платформи дистанційного навчання «Сікорський», відкрите віртуальне навчальне середовище КПІ ім. Ігоря Сікорського, яке надає адміністраторам, викладачам та студентам широкі можливості щодо застосування сучасних технологій дистанційного навчання, розроблення веб-ресурсів навчальних дисциплін, організації інтерактивної взаємодії між викладачами та студентами, а також управління дистанційним навчальним процесом.

Ключові слова: інформаційні комунікації, віртуальне навчальне середовище, сучасні інформаційні технології, системи дистанційного навчання, платформа дистанційного навчання. 